\title{
OM-704 A, A NEW ANTIBIOTIC ACTIVE AGAINST GRAM-POSITIVE BACTERIA PRODUCED BY STREPTOMYCES SP.
}

\section{Satoshi Ōmura, Yuzuru Iwai, Kiyoizumi Hinotozawa, Haruo Tanaka, YōKo TAKAHASHI and AKIRA NAKagawa \\ School of Pharmaceutical Sciences, Kitasato University and The Kitasato Institute, Minato-ku, Tokyo 108, Japan}

(Received for publication August 4, 1982)

\begin{abstract}
A new antibiotic OM-704 A has been isolated from a fermentation broth of a Streptomyces sp. OM-704, a soil isolate. It exhibits antibacterial activities against Gram-positive bacteria. The antibiotic $\left(\mathrm{mp} 291 \sim 295^{\circ} \mathrm{C}, \mathrm{C}_{20} \mathrm{H}_{22} \mathrm{~N}_{2} \mathrm{O}_{4}\right.$ ) is a neutral quinoid compound.
\end{abstract}

In the course of screening for antibacterial antibiotics from actinomycetes, a new antibiotic, OM$704 \mathrm{~A}$, has been isolated from the culture broth of strain OM-704, a soil isolate identified as Streptomyces sp. This antibiotic was active against Gram-positive bacteria.

The present paper deals with the taxonomy of strain OM-704 and the fermentation, isolation and biological and physicochemical properties of antibiotic OM-704 A.

\section{Taxonomy of the Producing Strain}

\section{Morphology}

The vegetative mycelium grows abundantly on both synthetic and complex agar media, and does not show fragmentation into coccoid or bacillary elements. Moderate or good growth of aerial mycelium was observed on various media.

The electronmicrographs of strain OM-704 were taken with a scanning electron microscope (Model S-430, Hitachi). Its sporophores show type Rectus-Flexibilis (Plate 1). Mature spore chains on inorganic salts-starch agar have more than ten spores per chain, which are cylindrical in shape, $0.57 \times 1.0 \mu \mathrm{m}$ in size and have a smooth surface

Plate 2. Scanning electronmicrograph of spore chains of strain OM-704. Bar represents $1.0 \mu \mathrm{m}$.

Plate 1. Scanning electronmicrograph of aerial hyphae of strain OM-704 $(\times 2,300)$.
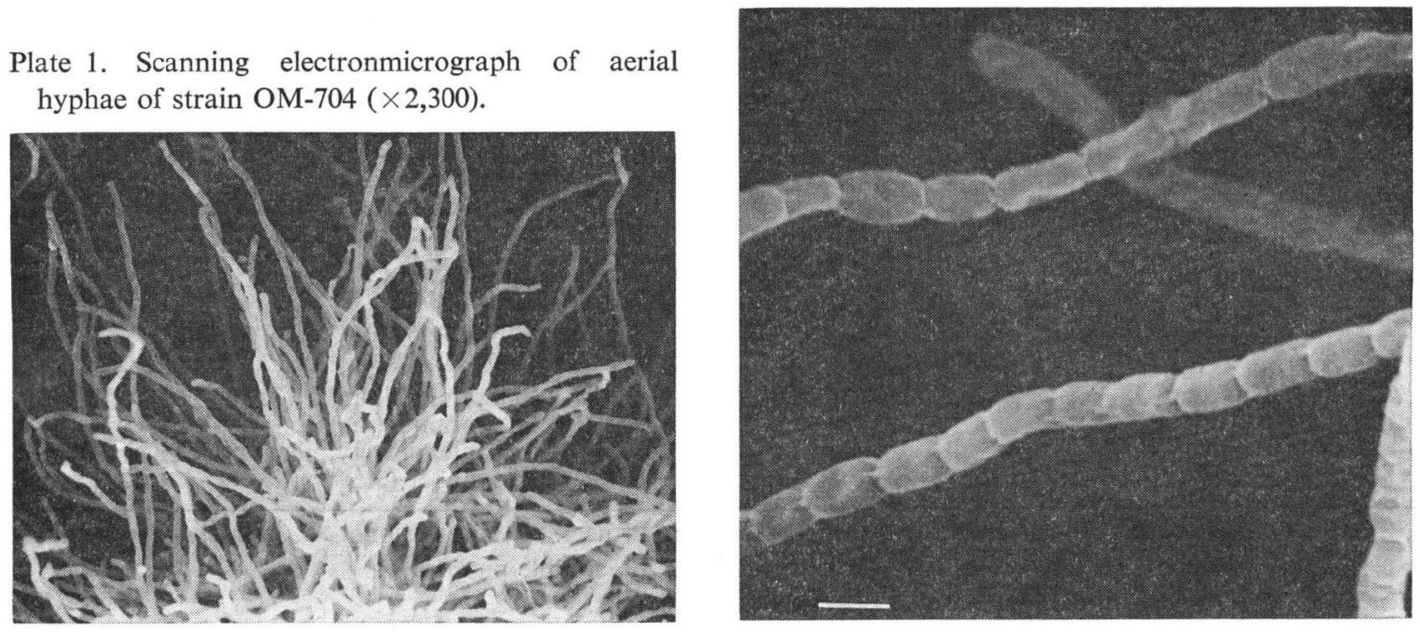
(Plate 2). Sclerotic granules, sporangia and flagellated spores were not observed.

\section{Chemical Compositions}

The chemical analyses of sugars in whole cells and amino acids in cell walls were carried out by the methods of Becker et al. ${ }^{1}$ ) and LeChevalier \& LeCHEVAlier, ${ }^{2)}$ respectively. Strain OM-704 shows no characteristic sugar pattern and LL-diaminopimelic acid (DAP) is present.

Table 1. Cultural characteristics of strain OM-704.

\begin{tabular}{|c|c|}
\hline Medium & Cultural characteristics \\
\hline Yeast extract-malt extract agar (ISP)* & $\begin{array}{l}\text { G : Good, light yellow (1 } 1 / 2 \text { ea) } \\
\mathrm{R}: \text { Light tan (3gc) } \\
\text { AM: Abundant, velvety, pearl (3ba) } \\
\text { SP : Slightly, camel (3ie) }\end{array}$ \\
\hline Oatmeal agar (ISP)* & $\begin{array}{l}\mathrm{G}: \text { Good, pastel yellow }(11 / 2 \mathrm{fb}) \\
\mathrm{R}: \text { Bamboo }(2 \mathrm{fb}) \\
\mathrm{AM}: \text { Abundant, velvety, pastel yellow (1db) } \\
\mathrm{SP}: \text { Slightly, camel (3ie) }\end{array}$ \\
\hline Inorganic salts-starch agar (ISP)* & $\begin{array}{l}\mathrm{G}: \text { Good, light antique gold }(11 / 2 \mathrm{ic}) \\
\mathrm{R}: \text { Light tan }(3 \mathrm{gc}) \\
\mathrm{AM}: \text { Abundant, velvety, ivory }(2 \mathrm{db}) \\
\mathrm{SP}: \text { Light orchid pink }(9 \mathrm{ca})\end{array}$ \\
\hline Glycerol-asparagine agar (ISP)* & $\begin{array}{l}\mathrm{G}: \text { Moderate, light cherry rose (7ga) } \\
\mathrm{R}: \text { Salmon pink ( } 5 \mathrm{ga}) \text {, light beige ( } 3 \mathrm{ec}) \\
\mathrm{AM}: \text { Abundant, velvety, white (a) } \\
\mathrm{SP}: \text { Slightly, light beige }(3 \mathrm{ec})\end{array}$ \\
\hline Glucose-asparagine agar & $\begin{array}{l}\mathrm{G}: \text { Good, pearl (2ba) } \\
\mathrm{R}: \text { Pale pink }(7 \mathrm{ca}), \text { bamboo }(2 \mathrm{gc}) \\
\mathrm{AM}: \text { Abundant, velvety, hygroscopic, white (a) } \\
\mathrm{SP}: \text { None }\end{array}$ \\
\hline Peptone-yeast extract iron agar (ISP)* & $\begin{array}{l}\mathrm{G}: \text { Good, rosewood tan }(5 \mathrm{ie}) \\
\mathrm{R}: \text { Light brown }(31 \mathrm{~g}) \\
\mathrm{AM}: \text { Poor, white }(\mathrm{a}) \\
\mathrm{SP}: \text { None }\end{array}$ \\
\hline Tyrosine agar (ISP)* & $\begin{array}{l}\mathrm{G}: \text { Moderate, light mustard tan (2ie) } \\
\mathrm{R}: \text { Light mustard tan (2ie) } \\
\mathrm{AM}: \text { Moderate, velvety, pearl (3ba) } \\
\mathrm{SP}: \text { None }\end{array}$ \\
\hline Sucrose-nitrate agar & $\begin{array}{l}\mathrm{G}: \text { Moderate, penetrant, coloress } \\
\mathrm{R}: \text { Pearl ( } 3 \text { ba) } \\
\mathrm{AM}: \text { Moderate, velvety, pearl ( } 3 \mathrm{ba}) \\
\mathrm{SP}: \text { None }\end{array}$ \\
\hline Glucose-nitrate agar & $\begin{array}{l}\mathrm{G}: \text { Good, light beige (3ec) } \\
\mathrm{R}: \text { Outer; light tan }(3 \mathrm{gc}) \\
\text { AM: Anner; light spice brown (41g) } \\
\text { SP : Nonndant, velvety, pearl (3ba) }\end{array}$ \\
\hline Glycerol-calcium malate agar & $\begin{array}{l}\mathrm{G}: \text { Moderate, cream }(11 / 2 \mathrm{ca}) \\
\mathrm{R}: \text { Ivory }(2 \mathrm{db}) \\
\mathrm{AM}: \text { Moderate, velvety, light ivory }(2 \mathrm{ca}) \\
\mathrm{SP}: \text { Slightly, bamboo }(2 \mathrm{gc})\end{array}$ \\
\hline Glucose-peptone agar & $\begin{array}{l}\mathrm{G}: \text { Good, camel (3ie) } \\
\mathrm{R}: \text { Cork tan (4ie) } \\
\mathrm{AM}: \text { Moderate, powdery, white (a) } \\
\mathrm{SP}: \text { Peach tan }(5 \mathrm{gc})\end{array}$ \\
\hline Nutrient agar & $\begin{array}{l}\mathrm{G}: \text { Moderate, pale pink (7ca) } \\
\mathrm{R}: \text { Pastel orange (4ic) } \\
\mathrm{AM}: \text { Moderate, velvety, pearl pink (4ca) } \\
\mathrm{SP}: \text { Light amber (3ic)** }\end{array}$ \\
\hline
\end{tabular}

* Medium employed by International Streptomyces Project. Abbreviations: G, growth of vegetative mycelium; R, reverse color; AM, aerial mycelium; SP, soluble pigment.

** Light amber soluble pigment was observed after 3 weeks. 
Table 2. Physiological properties of strain OM-704.

\begin{tabular}{l|l}
\hline Melanin formation & $\begin{array}{l}\text { Positive on glucose- } \\
\text { peptone gelatin }\left(21^{\circ} \mathrm{C}\right) \\
\text { Negative }\end{array}$ \\
Tyrosinase reaction & Negative \\
Nitrate reduction & Negative \\
$\mathrm{H}_{2} \mathrm{~S}$ production & Positive $\left(21^{\circ} \mathrm{C}\right)$ \\
Liquefaction of gelatin & Positive \\
Hydrolysis of starch & Positive $\left(37^{\circ} \mathrm{C}\right)$ \\
Coagulation of milk & Positive $\left(37^{\circ} \mathrm{C}\right)$ \\
Peptonization of milk & Negative \\
Cellulolytic activity & $15 \sim 40^{\circ} \mathrm{C}$ \\
Temperature range of & \\
growth & \\
\hline
\end{tabular}

Table 3. Utilization of carbon sources by strain OM-704.

\begin{tabular}{l|c|l|c}
\hline $\begin{array}{c}\text { Carbon } \\
\text { source }\end{array}$ & Response* & $\begin{array}{c}\text { Carbon } \\
\text { source }\end{array}$ & Response* \\
\hline $\begin{array}{l}\text { D-Glucose } \\
\text { D-Xylose }\end{array}$ & + & $\begin{array}{l}i \text {-Inositol } \\
\text { Raffinose }\end{array}$ & \pm \\
D-Mannitol & + & Sucrose & - \\
D-Fructose & + & Melibiose & - \\
L-Arabinose & \pm & & \\
\hline * $\quad$, Utilized, \\
$\quad$, weakly utilized, \\
$\quad$-, not utilized.
\end{tabular}

\section{Cultural and Physiological Characteristics}

The International Streptomyces Project (ISP) media recommended by SHIRLING and GotTLIEB ${ }^{3)}$ and those recommended by WAKSMAN ${ }^{4)}$ were used for these experiments. Cultures were observed after incubation at $27^{\circ} \mathrm{C}$ for two weeks. Color names and hue numbers indicated are those of the Color Harmony Manual (4th edition) published by the Container Cooperation of America. The utilization of carbon sources was tested by growth on PRIDHAM and GotTLIEB's medium containing $1 \%$ each carbon source at $27^{\circ} \mathrm{C}$. The cultural and physiological characteristics are shown in Tables 1 and 2, respectively. The utilization of carbon sources of strain OM-704 is shown in Table 3.

The cultural and physiological characteristics of strain OM-704 are summarized as follows: sporophore is Rectus-Flexibilis; spore is cylindrical and has a smooth surface; color of aerial mycelium is white to pearl; melanoid pigment is produced on glucose-peptone gelatin; soluble pigment is slightly yellowish brown; DAP in cell wall is LL-type. Based on the taxonomic properties described above, strain OM-704 is considered to belong to the genus Streptomyces being a strain of the white or red series of PRIDHAM and TRENSNER's grouping. ${ }^{5)}$ The type strain has been deposited in the Fermentation Research Institute, Agency of Industrial Science and Technology, Japan, as Streptomyces sp. OM-704-KA333 with the accession number FERM-P 6520.

Fermentation and Isolation

The stock culture of strain OM-704 was inoculated into $100 \mathrm{ml}$ of a seed medium consisting of $1.0 \%$ glucose, $2.0 \%$ starch, $0.5 \%$ yeast extract, $0.5 \%$ peptone, and $0.4 \% \mathrm{CaCO}_{3}$ in a $500-\mathrm{ml} \mathrm{Sakaguchi} \mathrm{flask}$

Fig. 1. Time course of antibiotic OM-704 A production in a 30 -liter jar fermentor.

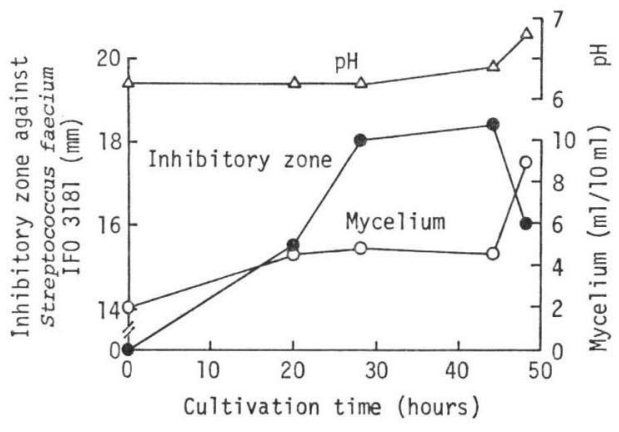
and incubated at $27^{\circ} \mathrm{C}$ for 48 hours. The seed culture thus obtained $(200 \mathrm{ml})$ was transferred to a production medium (20 liters) in a 30 -liter jar fermentor and the fermentation was carried out at $27^{\circ} \mathrm{C}$ for 48 hours with 10 liters of air per minute and agitation of $250 \mathrm{rpm}$. The composition of production medium was $0.5 \%$ glucose, $1.0 \%$ corn steep liquor, $1.0 \%$ oatmeal, $1.0 \%$ Pharmamedia, $0.5 \% \quad \mathrm{~K}_{2} \mathrm{HPO}_{4}, \quad 0.5 \%$ $\mathrm{MgSO}_{4} \cdot 7 \mathrm{H}_{2} \mathrm{O}, 0.001 \% \mathrm{FeSO}_{4} \cdot 7 \mathrm{H}_{2} \mathrm{O}, 0.001 \%$ $\mathrm{MnCl}_{2} \cdot 4 \mathrm{H}_{2} \mathrm{O}, \quad 0.001 \% \quad \mathrm{ZnSO}_{4} \cdot 7 \mathrm{H}_{2} \mathrm{O}, \quad 0.001 \%$ 
$\mathrm{CuSO}_{4} \cdot 5 \mathrm{H}_{2} \mathrm{O}$, and $0.001 \% \mathrm{CoCl}_{2} \cdot 2 \mathrm{H}_{2} \mathrm{O}$ (pH 7.0 before sterilization). A typical time course of the production of antibiotic OM-704 A by the strain OM-704 is shown in Fig. 1. The antibiotic activity was monitored by paper disk assay using Streptococcus faecium IFO 3181 as test organism.

A 48-hour culture (20 liters) was clarified with a Sharples centrifuge to give a supernatant (16 liters). The antibiotic in the supernatant was extracted with ethyl acetate (12 liters). After evaporation of the extract, the residue $(510 \mathrm{mg}$, a reddish orange powder) was chromatographed on silica gel column (Merck, Kieselgel 60, $20 \mathrm{~g}$ ) using a eluent of chloroform - methanol (20:1, v/v). The active fractions were combined and then concentrated in vacuo to afford a red powder $(120 \mathrm{mg})$. Red needles of antibiotic OM-704 A (96 mg) were obtained by crystallization from chloroform - methanol (9: 1, v/v).

\section{Physicochemical Properties}

Antibiotic OM-704 A is a red crystalline substance, $\mathrm{mp} 291 \sim 295^{\circ} \mathrm{C}$. The molecular formula was

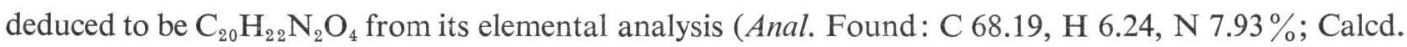
for $\mathrm{C}_{20} \mathrm{H}_{22} \mathrm{~N}_{2} \mathrm{O}_{4}$ : C 67.78, $\mathrm{H} 6.26, \mathrm{~N} 7.91 \%$ ) and high resolution mass spectrum $\left[\mathrm{M}^{+}, \mathrm{m} / \mathrm{z} 354.157\right.$; Calcd. for $\mathrm{C}_{20} \mathrm{H}_{22} \mathrm{~N}_{2} \mathrm{O}_{4}, m / z$ 354.157]. As shown in Fig. 2, the UV spectrum in methanol shows characteristic absorption maxima, at $250 \mathrm{~nm}(\varepsilon, 11,800, \mathrm{sh}), 260(13,600, \mathrm{sh}), 278(20,100, \mathrm{sh}), 286(21,700)$, $309(9,760), 321(8,950), 367(4,130)$ and $490(1,150)$. The IR spectrum (in KBr) exhibited characteristic bands based on methyl or methylene at $2960 \mathrm{~cm}^{-1}$ and quinone carbonyl group at $1670 \mathrm{~cm}^{-1}$ and $1625 \mathrm{~cm}^{-1}$, as shown in Fig. 3. The ${ }^{1} \mathrm{H}$ NMR spectrum in $\mathrm{CDCl}_{3}-\mathrm{CD}_{3} \mathrm{OD}$ indicates the presence of two methyl groups $[\delta 1.10(\mathrm{t})$ and $2.27(\mathrm{~s})]$ and two methylenes $[\delta 1.57(\mathrm{~m})$ and $3.03(\mathrm{t})]$, suggesting the presence of a symmetrical skeleton for the structure of the antibiotic OM-704 A. It is very slightly soluble in chloroform, ethyl acetate, acetone, dioxane, dimethylsulfoxide, ethanol and methanol, and practically insoluble in benzene, ethyl ether, $n$-hexane and water.

\section{Biological Properties}

The antibacterial spectrum of antibiotic OM-704 A was determined by conventional agar dilution method using heart infusion agar (Difco). As shown in Table 4, at concentrations of $3.13 \sim 50 \mu \mathrm{g} / \mathrm{ml}$, antibiotic OM-704 A inhibited the growth of Gram-positive bacteria, including Staphylococcus aureus FDA 209P, Staphylococcus aureus ATCC 6538P, Staphylococcus aureus FS 1277 (penicillin resistant), Staphylococcus aureus KB 199 (erythromycin resistant), and Streptococcus faecium IFO 3181, Micrococcus luteus ATCC 9341, but was inactive against Gram-negative bacteria and fungi. The acute toxicity

Fig. 2. UV spectrum of antibiotic OM-704 $\mathrm{A}_{2}^{-}$(in $\mathrm{MeOH})$.

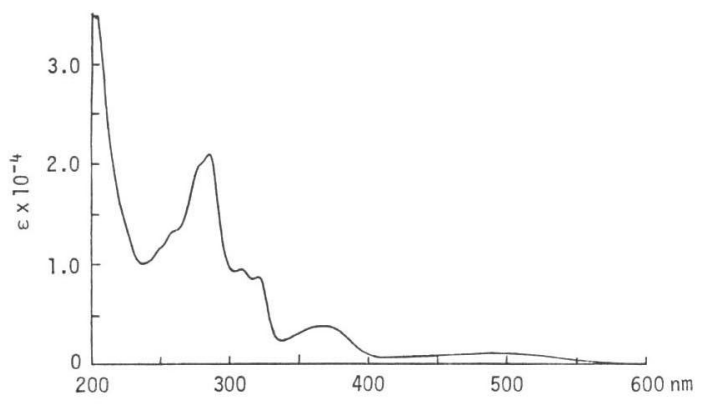

Fig. 3. IR spectrum of antibiotic OM-704 A (KBr).

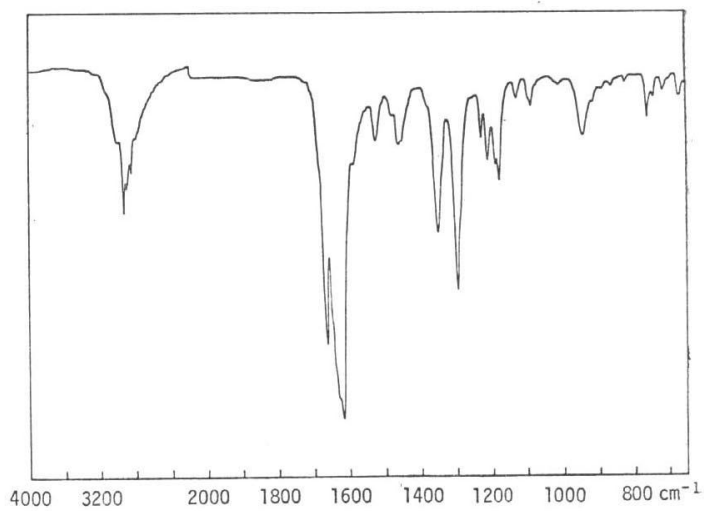


Table 4. Antibacterial spectrum of antibiotic OM-704 A.

\begin{tabular}{l|c|l|c}
\hline \multicolumn{1}{c|}{ Test organism } & $\begin{array}{c}\text { MIC } \\
(\mu \mathrm{g} / \mathrm{ml}) *\end{array}$ & \multicolumn{1}{c|}{ Test organism } & $\begin{array}{c}\text { MIC } \\
(\mu \mathrm{g} / \mathrm{ml})^{*}\end{array}$ \\
\hline Staphylococcus aureus FDA 209P & 6.25 & Bacillus subtilis ATCC 6633 & $>100$ \\
Staphylococcus aureus ATCC 6538P & 6.25 & Bacillus cereus IFO 3001 & $>100$ \\
$\begin{array}{l}\text { Staphylococcus aureus KB 199 } \\
\text { (erythromycin resistant) }\end{array}$ & 6.25 & Mycobacterium smegmatis ATCC 607 & 100 \\
$\begin{array}{l}\text { Staphylococcus aureus FS 1277 } \\
\text { (penicillin resistant) }\end{array}$ & 50 & Escherichia coli NIHJ JC-2 & $>100$ \\
$\begin{array}{l}\text { Streptococcus faecium IFO 3181 } \\
\text { Streptococcus pyogenes C 203 }\end{array}$ & 6.25 & Proteus vulgaris IFO 3167 & $>100$ \\
Micrococcus luteus ATCC 9341 & 100 & Serratia marcescens ATCC 8100 & $>100$ \\
\hline
\end{tabular}

* Minimal inhibitory concentrations were assayed by agar dilution method using heart infusion agar ( $\mathrm{pH}$ $7.0,37^{\circ} \mathrm{C}, 20$ hours).

$\left(\mathrm{LD}_{50}\right)$ of antibiotic OM-704 A in mice was $100 \mathrm{mg} / \mathrm{kg}$ intraperitoneally.

\section{Discussion}

From the above results, it was found that antibiotic OM-704 $\mathrm{A}$ is a neutral quinoid compound active against Gram-positive bacteria including an erythromycin-resistant strain of Staphylococcus. The antibiotic has characteristic UV-visible absorptions (286, 309, 321, 367 and $490 \mathrm{~nm})$. None of the known antibiotics has these absorptions. Consequently, the antibiotic is concluded to be a new compound. The structure elucidation is now in progress.

\section{Acknowledgement}

The authors wish to thank Miss Y. SuzuKı and Miss R. SATō for their assistance.

\section{References}

1) Becker, B.; M. P. Lechevalier, R. E. Gordon \& H. A. Lechevalier: Rapid differentiation between Nocardia and Streptomyces by paper chromatography of whole cell hydrolysates. Appl. Microbiol. 12: $421 \sim 432,1964$

2) Lechevalier, M. P. \& H. A. Lechevalier: The chemotaxonomy of actinomycetes. Textbook of Actinomycetes Taxonomy. Workshop, Soc. Ind. Microbiol., Aug. 13, 1978, pp. 1 49, 1978

3) Shirling, E. B. \& D. Gottlieb: Methods for characterization of Streptomyces species. Int. J. Syst. Bacteriol. 16: 313 340, 1966

4) Waksman, S. A.: The Actinomycetes. Vol. 2. The Williams \& Wilkins Co., Baltimore, 1961

5) Pridham, T. G. \& H. D. Tresner: Bergey's Manual of Determinative Bacteriology. 8th ed., pp. 748 829, The Williams \& Wilkins Co., Baltimore, 1974 